\title{
Face Mask or Face Shield?
}

\author{
Allana L. Harrylagan ${ }^{1}$ \\ ${ }^{1}$ Journal of Conceptual and Applied STEM Education
}

August 17, 2020

\section{SUGGESTED TIME}

50 minutes

\section{OVERVIEW}

Students will conduct testing to determine if face masks or face shields provide better protection of the user and of others around them, from droplet transmission of respiratory viruses expelled from the nose and mouth. Students will test existing designs of face masks and face shields. Students will then analyse the results of testing and re-design or design their own face mask or face shield to make a more efficient product. Students will test their own designs and present a comparison of their findings. Students will listen to each other's presentations then conclude if they feel safer using a face mask or face shield.

\section{VOCABULARY}

- Face Mask

- Face shield

- Respiratory viruses

- Droplet transmission

- Nose

- Mouth

- Engineering Design Process

- Design

- Re-design

\section{OBJECTIVES}

- Students will collaborate during the Engineering Design Process.

- Students will plan and design a more efficient product. 
- Students will collect data and analyse to make informed decisions.

- Students will discover the importance of testing products.

- Students will peer review each other and decide which product is more efficient.

\section{STANDARDS}

- MS-PS-1, MS-PS-4. Developing and Using Models.

- ETS1.A, B, and C. Defining and Delimiting Engineering Problems, Developing Possible Solutions, and Optimizing the Design Solution.

- MS-PS1-3. Obtaining, Evaluating, and Communicating Information.

- CCSS-ELA/Literacy W.7.1 Write arguments to support claims with clear reasons and relevant evidence. W.7.1.a Introduce claim(s), acknowledge alternate or opposing claims, and organize the reasons and evidence logically.

\section{REQUIRED MATERIALS}

- 4 High velocity spray bottles

- Food colouring of choice

- Distilled water

- Existing Face masks and face shields

- Various material to make face masks and face shields: cloth, transparent plastic (hard and soft), Velcro, elastic, felt, other cloth materials.

- Scissors

- Glue / Sticky Tape

- Four large cardboard boxes (same size)

- White copy paper for lining the inside of the cardboard boxes.

\section{OPTIONAL MULTIMEDIA RESOURCES}

- How Contagious is COVID-19? (Transmission, Spread, and R0)

- How Scientists Test Face Mask Effectiveness Against Coronavirus | NBC Nightly News

- Which face masks provide best protection l GMA

- Are Face Shields Better Than Masks For Coronavirus? - Cheddar Explains

\section{BACKGROUND TEACHER PREPARATION}

- Set up a pair of "testing stations" per group as shown in Worksheet \#2 - Testing Existing Designs

- Print one copy of Worksheet \#1 - Pre- Activity Assessment and Worksheet \#4 - Post- Activity Assessment per student.

- Print one copy of Worksheet \#2 - Testing Existing Designs, The Engineering Design Process and Worksheet \#3 - Design/Redesign and Test per group. 


\section{SAFETY GUIDELINES FOR STUDENTS}

- Wear safety glasses.

- Do not drink the coloured liquid.

- No horseplay, do not spray others.

\section{WORKSHEETS}

\section{Hosted file}

Worksheet \#1 - Pre-Acitvity Assessment Worksheet.pdf available at https://authorea.com/users/ 340372/articles/473664-face-mask-or-face-shield

\section{Hosted file}

Worksheet \#2 - Set up of testing stations and procedure for face masks and shields.pdf available at https://authorea.com/users/340372/articles/473664-face-mask-or-face-shield

\section{Hosted file}

Worksheet \#3 - Design or Redesign your face mask or face shield.pdf available at https:// authorea.com/users/340372/articles/473664-face-mask-or-face-shield

\section{Hosted file}

Worksheet \#4 - Post-Acitvity Assessment Worksheet.pdf available at https://authorea.com/ users/340372/articles/473664-face-mask-or-face-shield

The Engineering Design Process

\section{THE LESSON}

\section{Part 1: Pre- Activity Assessment (3 minutes)}

1. The teacher gives an overview of the activity to the students.

2. Students complete the Worksheet \#1 - Pre- Activity Assessment.

\section{Part 2: Testing Existing Designs (15 minutes)}

1. Break the class into two groups one for Face masks and the other for Face Shields.

2. Give each group a copy of "Worksheet \#2 - Testing existing Designs".

3. Have the students carry out the testing as instructed on the Worksheet.

\section{Part 3: Design/Redesign and Test (20 minutes)}

1. Give each group a copy of "The Engineering Design Process" and "Worksheet \#3 - Design/Redesign and Test." 
2. Have students complete the activity in "Worksheet \#3 - Design/Redesign and Test."

\section{Part 4: Communicate Results (12 minutes)}

1. Give each group a copy of the "Worksheet \#4 - Post- Activity Assessment".

2. Have each group present a short comparison between the existing designs and their new design. If the students believe that the existing design is efficient enough, they must explain why.

3 . Have the spectator groups peer assess the presenting group.

4. Have the students complete and hand in the "Post-Activity Assessment".

5. Collect all worksheets to be assessed.

\section{LESSON ADJUSTMENTS}

If more time is allotted to the lesson, less material can be used, eg. 2 boxes and 2 spray bottles instead of 4 each. More time will allow for more set up time and for testing more designs. 